\title{
Productivity of Different Patterns for Maize and Forage Millet Intercropping under Periodical Cutting Systems
}

\author{
A. M. Shaalan ${ }^{\#}$ and M.M. El-salamouni* \\ Faculty of Desert and Environmental Agriculture, Alexandria \\ University, Matrouh Branch and *Intertek Company for Cargo \\ Inspection, Alexandria, Egypt.
}

\begin{abstract}
AWO year study was conducted at Agricultural Research Station, Alexandria University, Egypt to investigate the productivity of maize and forage millet sown in different intercropping patterns, i.e, Rep 4:2 (four ridges of maize alternating with two ridges of millet), Rep 2:1 (two ridges of maize alternating with 1 ridge of millet), Add 1 (sowing of millet on the other side of the third and sixth ridges of maize) and Add 2 (sowing millet on the other side of the fifth, sixth, eleventh and twelfth ridges of maize). Forage millet was cut at three different periodical cutting systems, i.e, C1: 40-40-40, C2: 45-30-45 and C3: 45-45-30 days. The experimental design was split plot where intercropping patterns occupied the main plots and periodical cutting systems were allocated to the sub plots. Additive intercropping patterns (Add 1 and Add 2) had taller maize plants, yielded more grain yield and harvest index than replacement intercropping patterns (Rep 4:2 and Rep 2:1). Average grain yield reached $6.31,6.13,5.71$ and $5.98 \mathrm{t} / \mathrm{ha}$ for the four intercropping patterns, respectively. Periodical cutting systems varied significantly in grain yield of maize where $\mathrm{C} 1$ yielded $6.35 \mathrm{t} / \mathrm{ha}$, compared to $\mathrm{C} 2$ (5.95 t/ha) and C3 $(5.78 \mathrm{t} / \mathrm{ha})$ as an average of the two seasons. Association of maize and millet in additive patterns significantly reduced forage production compared to replacement patterns. Average total fresh weight of forage recorded 13.23, 11.30, 5.22 and 5.53 t/ha for Rep 4:2, Rep 2:1, Add 1 and Add 2 patterns, respectively. The total fresh forage weight reached 8.51 , 7.84 and 10.11 t/ha for $\mathrm{C} 1, \mathrm{C} 2$ and $\mathrm{C} 3$, respectively. The dry matter equivalent ratio indicated a slight increase in total dry matter production, for the additive compared to replacement intercropping patterns.
\end{abstract}

Keywords: Maize, Millet, Intercropping, Yield, Periodical Cutting systems.

Cereals are cultivated for several uses including productivity of fodder for livestock and food for mankind (Anil et al., 1998). Egyptian maize producers defoliate and detassel maize plants to obtain green fodder for animals feed. They also delay maize thinning, being at different intervals, and /or convert an area from maize cultivated area to be grown as a fodder maize crop at the expense of grain maize productivity. A dimensional association, in time and space, of two or more crops is an important form of crop intensification. Intercropping, in most cases, ensures more land utilization, compared to sole cropping (Khalil \& Nawar, 2004). Arrival at land yield advantage is a better utility of growth factors and better control of pests (Vandermeer, 1989). Suitable intercropping system has intercrops that are able to share growth factors \#Corresponding author e-mail: ahmedmahgoub@alexu.edu.eg 
(Francis \& Decoteau, 1993). Degrees of resources uptake will depend upon the intercrops contact ratios which are related to plant population density in addition to plant size (Willy, 1979 "a and "b"). With regard to intercropping density, plants are arranged in a range from replacement to additive intercropping density (Fukai \& Trenbath, 1993). In replacement intercropping, the overall population density is the same in monoculture as in the intercrop, whereas, it is sometimes greater in the additive intercropping than monoculture cropping. Raising productivity from intercropping is possible provided that demands of component crops for growth resources are well understood, followed by the intercrop management that leads to maximum complementarity and minimum competition. If not, agriculture manipulation should be applied, especially with intercrops of the same growth habits. Cereal- cereal intercropping has obvious advantages in comparison with their sole cropping, regarding mobilization of different resources and/or using the same resources more efficiently over time and space (Wolfe, 2000 and Shaalan et al., 2015). In a successful intercropping pattern of crops similar in maturity, there should be a delay in turnover point between complementarity and competition for growth factors (Francis \& Decoteau, 1993). That process could be by the manipulation of growth environment. Cutting of pearl millet as a component crop with maize eliminates intercrops competition at critical growth stages of maize (Midmore, 1993; Gao et al., 2009; Zhu et al., 2015 and Gou et al., 2016). In this investigation, the author used the concept of dry matter equivalent ratio (Shaalan et al., 2015) as an index to compare additive with replacement intercropping patterns. This investigation was conducted to examine the response of grain maize and fodder millet to additive and replacement intercropping patterns under different periodical cutting systems of millet.

\section{Materials and Methods}

A two-year field study was conducted during 2013 and 2014 summer seasons at Agriculture Research Station, Alexandria University, Egypt to investigate the productivity of grain maize (three way cross, Giza 310) and fodder millet (Shandweel 1 cv.) grown in association as replacement or additive models under 3 different periodical cutting systems of millet. Replacement (Rep) patterns were Rep 4: 2 (four ridges of maize alternating with two ridges of millet) and Rep 2:1 (two ridges of maize alternating with 1 ridge of millet). Additive (Add) intercropping patterns were sowing millet on the other side of maize ridges, Add 1 (sowing of millet on the other side of the third and sixth ridges of maize) and Add 2 (sowing millet on the other side of the fifth, sixth, eleventh and twelfth ridges of maize). Periodical cutting systems of millet were as follows: 40, 40 and 40 (C1); 45, 30 and 45 (C2) in addition to 45, 45 and 30 days (C3). Split plot design with three replicates was used, where intercropping patterns and periodical cutting systems were, respectively, allocated to the main and sub plots. Each sub plot comprised 12 ridges, each $3.0 \mathrm{~m}$ long and $0.7 \mathrm{~m}$ wide (sub plot area $=25.2 \mathrm{~m}^{2}$ ). Plants were grown in hills spaced $25 \mathrm{~cm}$ a part with one plant/hill for maize. However, millet was drilled, at the rate of $48.0 \mathrm{~kg} / \mathrm{ha}$, at designated sides of ridges according to each additive cropping system. Grain maize and fodder millet were grown as pure crops as recommended. Soil chemical characters were $\mathrm{pH}=8.2$, total organic matter $=1.1 \%$, available $\mathrm{N}=33.6 \mathrm{ppm}$, available $\mathrm{P}=10.5 \mathrm{ppm}$ and available $\mathrm{K}=610.0 \mathrm{ppm}$. The two intercrop components were sown on 10 and $15 \mathrm{May}$ in the first Egypt. J. Agron. 38, No. 3 (2016) 
and second season, respectively. All other agricultural practices were applied as recommended for each crop in the region.

Ridges sown with millet were cut at soil surface to calculate fresh fodder weight (t/ha) for each of the millet cuts according to the designated periodical cutting systems, and percentage of dry matter millet (as an average of two $0.3 \mathrm{~m}$ sample, taken at random from each sub plot). Dry weight of maize and forage millet were calculated from an oven-dried sample at $70{ }^{\circ} \mathrm{C}$ till a constant weight. Expression of intercropping advantage was estimated as dry matter equivalent ratio (DMER) concept proposed by Shaalan et al. (2015) as follows:

DMER $=$ Dry matter of intercrop grain maize + dry matter of fodder/dry matter of pure grain maize

when DMER $\leq 1$, there is no advantage to intercropping, in comparison with pure crop, however, when, it is $>1$, there is intercropping yield advantage.

At harvest, maize plants of the total number of ridges of each sub plot were cut near soil surface. Characters recorded for grain maize were plant height $(\mathrm{cm})$, ear height $(\mathrm{cm})$ and ear leaf area $\left(\mathrm{cm}^{2}\right)$ as the average of 5 guarded plants, taken at random from each sub plot. A sample of 5 ears were randomly taken from each sub plot to calculate ear grain weight (g). 100-grain weight (g) was calculated as the average of three 100grain random samples, taken from each sub plot. Grain yield was calculated from the all ridges of each sub plot, then converted to $t /$ ha. Data were subjected to the proper analysis according to Gomez \& Gomez (1984) using SAS (Statistical Analyses Systems, 2007). Means were compared, using the least significant difference (LSD) value at $5 \%$ level of probability.

\section{Results}

Maize characters as affected by intercropping patterns and periodical cutting systems

Data in Table 1 present maize characters as affected by different intercropping systems with millet, different periodical cutting systems of millet and the interaction of both factors in the two seasons. Response of maize plant height, grain yield and harvest index to intercropping patterns were significant. Additive intercropping gave higher values regarding plant height, grain yield and harvest index compared to replacement patterns. Plant heights were, respectively, $286.13,279.47,309.77$ and $313.10 \mathrm{~cm}$, as an average of the two seasons, for Rep 4:2, Rep 2:1, Add 1 and Add 2. Grain yield of maize intercropped with millet in replacement treatments were significantly lower than being grown with millet in additive intercropping. Minimum and maximum values (5.71 and $6.31 \mathrm{t} / \mathrm{ha}$ ) were obtained from Rep 4:2 and Add 1 over the two seasons. It should be noted that the harvest index showed the same trend of change as plant height where the average of its values were recorded as 32.48, 32.80, 35.12 and $33.83 \%$ for Rep 4:2, Rep 2:1, Add 1 and Add 2, respectively. 
TABLE 1. Means of studied characters for maize, as affected by intercropping patterns and periodical cutting systems during 2013 and 2014 seasons.

\begin{tabular}{|c|c|c|c|c|c|c|c|}
\hline Characters & $\begin{array}{c}\text { Plant } \\
\text { height } \\
(\mathbf{c m})\end{array}$ & $\begin{array}{c}\text { Ear } \\
\text { height } \\
(\mathbf{c m})\end{array}$ & $\begin{array}{c}\text { Ear leaf } \\
\text { area } \\
\left(\mathrm{cm}^{2}\right)\end{array}$ & $\begin{array}{c}\text { 100- } \\
\text { grain } \\
\text { weight } \\
\text { (g) }\end{array}$ & $\begin{array}{l}\text { Ear grain } \\
\text { weight (g) }\end{array}$ & $\begin{array}{c}\text { Grain } \\
\text { yield } \\
\text { t/ha }\end{array}$ & $\begin{array}{c}\text { Harvest } \\
\text { index } \\
(\%)\end{array}$ \\
\hline patterns & \multicolumn{7}{|c|}{2013 season } \\
\hline Rep 4:2 & $288.95 \mathrm{~b}^{*}$ & $131.04 \mathrm{a}$ & $517.10 \mathrm{a}$ & $38.44 \mathrm{a}$ & $250.31 \mathrm{a}$ & $5.94 \mathrm{c}$ & $34.12 \mathrm{~b}$ \\
\hline Rep 2:1 & $282.23 \mathrm{~b}$ & $119.39 \mathrm{a}$ & $519.12 \mathrm{a}$ & $40.83 \mathrm{a}$ & $280.40 \mathrm{a}$ & $6.22 \mathrm{bc}$ & $34.45 \mathrm{~b}$ \\
\hline Add 1 & $312.83 \mathrm{a}$ & $141.86 \mathrm{a}$ & $483.84 \mathrm{a}$ & $36.30 \mathrm{a}$ & $240.76 \mathrm{a}$ & $6.52 \mathrm{a}$ & $36.89 \mathrm{a}$ \\
\hline Add 2 & $316.20 \mathrm{a}$ & $149.34 \mathrm{a}$ & $402.19 \mathrm{a}$ & $35.71 \mathrm{a}$ & $230.54 \mathrm{a}$ & $6.37 \mathrm{ab}$ & $35.53 \mathrm{a}$ \\
\hline \multicolumn{8}{|c|}{ Periodical cutting systems: } \\
\hline C1: $40-40-40$ & $288.57 \mathrm{~b}$ & $130.21 \mathrm{a}$ & $527.23 \mathrm{a}$ & $38.95 \mathrm{a}$ & $270.30 \mathrm{a}$ & $6.59 \mathrm{a}$ & $35.76 \mathrm{a}$ \\
\hline C2: $45-30-45$ & $304.78 \mathrm{a}$ & $135.51 \mathrm{a}$ & $479.94 \mathrm{~b}$ & $38.29 \mathrm{a}$ & $250.74 \mathrm{ab}$ & $6.17 \mathrm{~b}$ & $35.13 \mathrm{a}$ \\
\hline C3: $45-45-30$ & $306.82 \mathrm{a}$ & $140.50 \mathrm{a}$ & $434.51 \mathrm{c}$ & $36.23 \mathrm{a}$ & $230.47 \mathrm{~b}$ & $6.01 \mathrm{~b}$ & $34.85 \mathrm{a}$ \\
\hline Interaction & $* *$ & NS & $\mathbf{N S}$ & NS & $*$ & $*$ & NS \\
\hline & \multicolumn{7}{|c|}{2014 season } \\
\hline \multicolumn{8}{|c|}{ Intercropping patterns: } \\
\hline Rep 4:2 & $283.31 \mathrm{~b}$ & $126.00 \mathrm{a}$ & $513.41 \mathrm{a}$ & $35.66 \mathrm{a}$ & $231.43 \mathrm{a}$ & $5.48 \mathrm{c}$ & $30.84 \mathrm{~b}$ \\
\hline Rep 2:1 & $276.70 \mathrm{~b}$ & $114.80 \mathrm{a}$ & $515.13 \mathrm{a}$ & $37.88 \mathrm{a}$ & $254.67 \mathrm{a}$ & $5.73 \mathrm{bc}$ & $31.14 \mathrm{~b}$ \\
\hline Add 1 & $306.72 \mathrm{a}$ & $136.40 \mathrm{a}$ & $480.18 \mathrm{a}$ & $33.67 \mathrm{a}$ & $223.91 \mathrm{a}$ & $6.09 \mathrm{a}$ & $33.35 \mathrm{a}$ \\
\hline Add 2 & $310.00 \mathrm{a}$ & $143.60 \mathrm{a}$ & $399.33 \mathrm{a}$ & $33.13 \mathrm{a}$ & $210.32 \mathrm{a}$ & $5.88 \mathrm{ab}$ & $32.12 \mathrm{a}$ \\
\hline \multicolumn{8}{|c|}{ Periodical cutting systems: } \\
\hline C1: 40-40-40 & $282.90 \mathrm{~b}$ & $125.20 \mathrm{a}$ & $522.17 \mathrm{a}$ & $36.13 \mathrm{a}$ & $247.31 \mathrm{a}$ & $6.10 \mathrm{a}$ & $32.28 \mathrm{a}$ \\
\hline $\mathrm{C} 2: 45-30-45$ & $298.80 \mathrm{a}$ & $130.30 \mathrm{a}$ & $476.43 \mathrm{~b}$ & $35.52 \mathrm{a}$ & $232.81 \mathrm{ab}$ & $5.73 \mathrm{~b}$ & $31.46 \mathrm{a}$ \\
\hline C3: $45-45-30$ & $300.80 \mathrm{a}$ & $135.10 \mathrm{a}$ & $432.43 \mathrm{c}$ & $33.60 \mathrm{a}$ & $210.12 \mathrm{~b}$ & $5.55 \mathrm{~b}$ & $31.84 \mathrm{a}$ \\
\hline Interaction & $* *$ & NS & NS & NS & $*$ & $*$ & NS \\
\hline
\end{tabular}

* Means in the same column followed by the same letter (s) were not significantly at 0.05 level of probability.

Response of maize traits to periodical cutting systems of millet were significant for plant height, ear leaf area, ear-grain weight and grain yield, in the two seasons. When maize was intercropped with millet cut at 40,40 and 40 days period $(\mathrm{C} 1)$, it gave the lowest plant height values $(288.57$ and $282.90 \mathrm{~cm})$ compared to higher values $(306.82$ and $300.80 \mathrm{~cm}$ ), respectively, in the two seasons, recorded for cutting millet at 45, 45 and 30 days (C3) in both seasons. Reduction in plant height for $\mathrm{C} 1$, compared, to $\mathrm{C} 2$ and $\mathrm{C} 3$ were 16.21 and $18.25 \mathrm{~cm}$ in the first season, and 15.9 and $17.9 \mathrm{~cm}$ in the second season, respectively. Variations in maize ear leaf area, were significant in both seasons, to be ranked first, second and third with periodical cutting systems of $\mathrm{C} 1, \mathrm{C} 2$ and $\mathrm{C} 3$, respectively. There were significant differences in ear grain weight between $\mathrm{C} 1$ and $\mathrm{C} 3$ periodical cutting systems. As an average of the two seasons, responses of ear weight to $\mathrm{C} 1, \mathrm{C} 2$ and $\mathrm{C} 3$ were, respectively, $258.81,241.78$ and $220.30 \mathrm{~g}$.

$\mathrm{C} 2$ and $\mathrm{C} 3$ periodical cutting systems were statistically equal and significantly lower in grain yield than $\mathrm{C} 1$ system. Grain yield for $\mathrm{C} 1$ was higher than $\mathrm{C} 2$ and $\mathrm{C} 3$ by 0.42 and $0.58 \mathrm{t} / \mathrm{ha}$ in the first season and by 0.37 and 0.55 in the second season. Data showed that higher grain yield gave higher values for harvest index, though differences were insignificant between periodical cutting systems in both seasons. That may

Egypt. J. Agron. 38, No. 3 (2016) 
indicate an increase in grain yield relative to straw yield for additive intercropping compared to replacement intercropping. These results were confirmed by Shaalan et al. (2015).

The interaction between intercropping patterns and periodical cutting systems

Differences in plant height for the interaction effect of the two factors (intercropping patterns x periodical cutting systems) in both seasons, revealed that the higher plant height $(320.19 \mathrm{~cm})$ was obtained from Add 2 at $\mathrm{C} 2$, whereas, the lowest mean $(259.44 \mathrm{~cm})$, as average of two seasons, for that trait resulted from Rep 2:1 x C1 combination (Table 2). Replacement patterns showed significant differences in plant height where means at $\mathrm{C} 2$ and $\mathrm{C} 3$ periodical cutting systems were of significantly higher values than $\mathrm{C} 1$. However, Add patterns gave statistically similar maize plant height at all periodical cutting systems, in both seasons.

TABLE 2. Plant height, ear grain weight and grain yield as affected by interaction between intercropping patterns and periodical cutting systems in 2013 and 2014 seasons.

\begin{tabular}{|c|c|c|c|c|c|c|}
\hline \multirow{3}{*}{$\begin{array}{l}\text { Chtercropping } \\
\text { patterns }\end{array}$} & \multicolumn{6}{|c|}{ Plant height (cm) } \\
\hline & \multicolumn{3}{|c|}{2013 season } & \multicolumn{3}{|c|}{2014 season } \\
\hline & C1 & C2 & $\mathbf{C 3}$ & C1 & $\mathrm{C} 2$ & $\mathrm{C3}$ \\
\hline $\operatorname{Rep} 4: 2$ & 272.24 & 295.46 & 299.19 & 268.20 & 284.30 & 297.40 \\
\hline Rep 2:1 & 257.38 & 289.76 & 299.53 & 261.50 & 277.40 & 291.20 \\
\hline Add 1 & 312.78 & 313.36 & 312.33 & 298.20 & 313.70 & 308.20 \\
\hline Add 2 & 311.83 & 320.57 & 316.24 & 303.70 & 319.80 & 306.50 \\
\hline \multirow[t]{4}{*}{ LSD 0.05} & \multicolumn{3}{|c|}{19.34} & \multicolumn{3}{|c|}{15.22} \\
\hline & \multicolumn{6}{|c|}{ Ear grain weight (g) } \\
\hline & \multicolumn{3}{|c|}{2013 season } & \multicolumn{3}{|c|}{2014 season } \\
\hline & C1 & C2 & $\mathbf{C 3}$ & C1 & C2 & C3 \\
\hline Rep 4:2 & 278.27 & 253.10 & 219.57 & 255.30 & 240.21 & 198.78 \\
\hline Rep 2:1 & 295.40 & 275.31 & 270.50 & 270.22 & 258.76 & 235.04 \\
\hline Add 1 & 267.52 & 248.44 & 206.33 & 244.63 & 222.17 & 204.94 \\
\hline Add 2 & 240.03 & 226.11 & 225.51 & 219.09 & 210.10 & 201.77 \\
\hline \multirow[t]{4}{*}{ LSD 0.05} & & 25.30 & & & 19.42 & \\
\hline & \multicolumn{6}{|c|}{ Grain yield (t/ha) } \\
\hline & \multicolumn{3}{|c|}{2013 season } & \multicolumn{3}{|c|}{2014 season } \\
\hline & C1 & $\mathbf{C 2}$ & $\mathbf{C 3}$ & C1 & $\mathbf{C 2}$ & $\mathbf{C 3}$ \\
\hline Rep 4:2 & 6.14 & 5.95 & 5.73 & 5.62 & 5.59 & 5.23 \\
\hline Rep 2:1 & 6.41 & 6.18 & 6.07 & 5.81 & 5.77 & 5.61 \\
\hline Add 1 & 6.97 & 6.32 & 6.27 & 6.54 & 5.97 & 5.76 \\
\hline Add 2 & 6.84 & 6.24 & 6.03 & 6.43 & 5.59 & 5.62 \\
\hline LSD 0.05 & \multicolumn{3}{|c|}{0.22} & \multicolumn{3}{|c|}{0.36} \\
\hline
\end{tabular}

Response of ear grain weight to intercropping patterns x periodical cutting systems interaction were also significant in both seasons. Highest value $(282.81 \mathrm{~g})$ was obtained at Rep 2:1 and C1, whereas the lowest ear grain weight $(205.64 \mathrm{~g})$ was recorded for Add 1 and C3, or Rep 4:2 and C3 (209.18 g), as average of two seasons. Rep 4:2 and Add 1 revealed significant decrease in ear grain weight values between $\mathrm{C} 2$ and $\mathrm{C} 3$ in the first season, whereas, Rep 2:1 and Add 2 showed insignificant variation, in that trait, between all periodical cutting systems. In the second season, the Rep patterns showed significant decrease in ear grain weight between C2 and C3 cutting systems, whereas 
the two Add patterns varied insignificantly across the three periodical cutting systems. Concerning grain yield, in both seasons, the highest and lowest yields (6.75and 5.48 t/ha), as an average of the two seasons, were obtained from Add 1 x C1 and Rep 4:2 x C3, respectively. Moreover, Rep patterns showed insignificant decrease in grain yield from $\mathrm{C} 1$ to $\mathrm{C} 2$ and $\mathrm{C} 2$ to $\mathrm{C} 3$ except Rep 2:1 from $\mathrm{C} 1$ to $\mathrm{C} 2$, while Add patterns showed significant decrease in that character from $\mathrm{C} 1$ to $\mathrm{C} 2$ only.

Millet characters as affected by intercropping patterns and periodical cutting systems

Data in Table 3 present the fresh weight and percentage of dry weight of fodder millet during the two seasons. Differences between the intercropping patterns regarding total fresh weight were significant in both seasons. Replacement intercropping produced significantly higher total fresh fodder yield, compared to the additive patterns (which were statistically similar), over the three millet periodical

cutting systems. However, differences in total fresh weight were significant between Rep 4:2 and Rep 2:1. Average total fresh weights of fodder yield, over the two seasons, were 13.23, 11.30, 5.22 and 5.53 t/ha for Rep 4:2, Rep 2:1, Add 1 and Add 2 patterns, respectively. Fodder millet total fresh weight varied significantly with the three different cutting periods, where values for $\mathrm{C} 1, \mathrm{C} 2$ and $\mathrm{C} 3$ respectively, amounted to $8.51,7.85$ and $10.11 \mathrm{t} / \mathrm{ha}$, as an average of the two seasons.

TABLE 3. Means of studied characters, as affected by intercropping patterns and periodical cutting systems in 2013 and 2014 seasons.

\begin{tabular}{|c|c|c|c|c|c|c|c|}
\hline \multirow{2}{*}{ Characters } & \multicolumn{2}{|c|}{ Cutting 1} & \multicolumn{2}{|c|}{ Cutting 2} & \multicolumn{2}{|c|}{ Cutting 3} & \multirow[b]{2}{*}{$\begin{array}{c}\text { Total fresh } \\
\text { weight } \\
\text { (t/ha) }\end{array}$} \\
\hline & $\begin{array}{c}\text { Fresh } \\
\text { weight } \\
\text { tha }\end{array}$ & $\begin{array}{c}\text { Dry weight } \\
\%\end{array}$ & $\begin{array}{c}\text { Fresh } \\
\text { weight } \\
\text { t/ha }\end{array}$ & $\begin{array}{c}\text { Dry } \\
\text { weight } \\
\%\end{array}$ & $\begin{array}{c}\text { Fresh weight } \\
\text { tha }\end{array}$ & $\begin{array}{c}\text { Dry } \\
\text { weight } \\
\%\end{array}$ & \\
\hline \multicolumn{8}{|c|}{2013 season } \\
\hline \multicolumn{8}{|c|}{ Intercropping patterns: } \\
\hline Rep 4:2 & $3.96 \mathrm{a}^{*}$ & $15.99 \mathrm{a}$ & $6.41 \mathrm{a}$ & $22.63 \mathrm{a}$ & $1.82 \mathrm{a}$ & $24.60 \mathrm{a}$ & $12.19 \mathrm{a}$ \\
\hline Rep 2:1 & $3.38 \mathrm{a}$ & $15.35 \mathrm{a}$ & $5.48 \mathrm{a}$ & $22.74 \mathrm{a}$ & $1.55 \mathrm{a}$ & $27.26 \mathrm{a}$ & $10.41 \mathrm{~b}$ \\
\hline Add 1 & $1.56 \mathrm{~b}$ & $14.82 \mathrm{a}$ & $2.53 \mathrm{~b}$ & $21.18 \mathrm{a}$ & $0.72 \mathrm{~b}$ & $28.55 \mathrm{a}$ & $4.81 \mathrm{c}$ \\
\hline Add 2 & $1.66 \mathrm{~b}$ & $14.83 \mathrm{a}$ & $2.68 \mathrm{~b}$ & $20.62 \mathrm{a}$ & $0.76 \mathrm{~b}$ & $27.17 \mathrm{a}$ & $5.10 \mathrm{c}$ \\
\hline \multicolumn{8}{|c|}{ Periodical cutting systems: } \\
\hline C1: $40-40-40$ & $2.30 \mathrm{a}$ & $15.15 \mathrm{a}$ & $4.35 \mathrm{~b}$ & $21.40 \mathrm{a}$ & $1.18 \mathrm{~b}$ & $26.99 \mathrm{a}$ & $7.83 \mathrm{~b}$ \\
\hline C2: 45-30-45 & $2.29 \mathrm{a}$ & $16.26 \mathrm{a}$ & $3.53 \mathrm{c}$ & $21.92 \mathrm{a}$ & $1.42 \mathrm{a}$ & $28.28 \mathrm{a}$ & $7.24 \mathrm{~b}$ \\
\hline C3: $45-45-30$ & $2.34 \mathrm{a}$ & $14.32 \mathrm{a}$ & $5.95 \mathrm{a}$ & $22.05 \mathrm{a}$ & $1.02 \mathrm{~b}$ & $25.42 \mathrm{a}$ & $9.31 \mathrm{a}$ \\
\hline Interaction & $\mathbf{N S}$ & NS & NS & NS & NS & NS & \\
\hline \multicolumn{8}{|c|}{2014 season } \\
\hline \multicolumn{8}{|c|}{ Intercropping patterns: } \\
\hline Rep 4:2 & $4.66 \mathrm{a}$ & $16.67 \mathrm{a}$ & $7.46 \mathrm{a}$ & $23.01 \mathrm{a}$ & $2.16 \mathrm{a}$ & $26.30 \mathrm{a}$ & $14.28 \mathrm{a}$ \\
\hline $\operatorname{Rep} 2: 1$ & $3.98 \mathrm{a}$ & $16.00 \mathrm{a}$ & $6.37 \mathrm{a}$ & $23.12 \mathrm{a}$ & $1.85 \mathrm{a}$ & $29.20 \mathrm{a}$ & $12.19 \mathrm{~b}$ \\
\hline Add 1 & $1.84 \mathrm{~b}$ & $15.44 \mathrm{a}$ & $2.94 \mathrm{~b}$ & $21.53 \mathrm{a}$ & $0.85 \mathrm{~b}$ & $30.60 \mathrm{a}$ & $5.64 \mathrm{c}$ \\
\hline Add 2 & $1.95 \mathrm{~b}$ & $15.45 \mathrm{a}$ & $3.12 \mathrm{~b}$ & $20.96 \mathrm{a}$ & $0.90 \mathrm{~b}$ & $29.10 \mathrm{a}$ & $5.97 \mathrm{c}$ \\
\hline \multicolumn{8}{|c|}{ Periodical cutting systems: } \\
\hline C1: $40-40-40$ & $2.71 \mathrm{a}$ & $15.79 \mathrm{a}$ & $5.06 \mathrm{~b}$ & $21.76 \mathrm{a}$ & $1.41 \mathrm{~b}$ & $28.90 \mathrm{a}$ & $9.18 \mathrm{~b}$ \\
\hline C2: $45-30-45$ & $2.69 \mathrm{a}$ & $16.96 \mathrm{a}$ & $4.09 \mathrm{c}$ & $22.29 \mathrm{a}$ & $1.69 \mathrm{a}$ & $30.30 \mathrm{a}$ & $8.47 \mathrm{~b}$ \\
\hline C3: $45-45-30$ & $2.93 \mathrm{a}$ & $14.92 \mathrm{a}$ & $6.76 \mathrm{a}$ & $22.42 \mathrm{a}$ & $1.22 \mathrm{~b}$ & $27.20 \mathrm{a}$ & $10.91 \mathrm{a}$ \\
\hline Interaction & NS & NS & NS & NS & NS & NS & \\
\hline
\end{tabular}

* Means in the same column followed by the same letter (s) were not significantly at 0.05 level of probability.

Egypt. J. Agron. 38, No. 3 (2016) 
Biological evaluation of grain maizelfodder millet intercropping:

Data in Table 4 indicated that not all intercrop combinations gave more yield advantage than grain yield of sole cropped maize. Additive was more advantageous than replacement intercropping since the latter showed no yield advantage (DMER < 1), compared to the former intercropping patterns which gave estimates slightly greater than 1 . Regarding the effect of periodical cutting systems on intercropping advantage, the three cutting systems had values greater than one. These values were 1.09, 1.04 and 1.04, and 1.11, 1.07 and 1.05 in the first and second season for $\mathrm{C} 1, \mathrm{C} 2$ and $\mathrm{C} 3$, respectively.

TABLE 4. Dry matter production, DMER for grain maize and forage millet as affected by intercropping patterns and periodical cutting systems in 2013 and 2014 seasons.

\begin{tabular}{|c|c|c|c|c|c|}
\hline Treatments & $\begin{array}{c}\text { Grain } \\
\text { yield } \\
\text { t/ha }\end{array}$ & $\begin{array}{c}\text { Straw } \\
\text { yield } \\
\text { t/ha }\end{array}$ & $\begin{array}{c}\text { Millet dry } \\
\text { matter } \\
\text { t/ha }\end{array}$ & $\begin{array}{c}\text { Total dry } \\
\text { matter } \\
\text { t/ha }\end{array}$ & $\begin{array}{c}\text { Dry matter } \\
\text { equivalent ratio } \\
\text { (DMER) * }\end{array}$ \\
\hline \multicolumn{6}{|c|}{2013 season } \\
\hline \multicolumn{6}{|c|}{ Intercropping patterns: } \\
\hline $\operatorname{Rep} 4: 2$ & 5.71 & 7.76 & 2.52 & 15.99 & 0.90 \\
\hline Rep 2:1 & 5.98 & 7.58 & 2.17 & 15.82 & 0.89 \\
\hline Add 1 & 6.27 & 10.72 & 0.96 & 17.95 & 1.01 \\
\hline Add 2 & 6.13 & 11.12 & 0.99 & 18.24 & 1.03 \\
\hline \multicolumn{6}{|c|}{ Periodical cutting systems: } \\
\hline C1: $40-40-40$ & 6.34 & 11.38 & 1.58 & 19.3 & 1.09 \\
\hline C2: $45-30-45$ & 5.93 & 10.95 & 1.54 & 18.42 & 1.04 \\
\hline C3: $45-45-30$ & 5.78 & 10.8 & 1.89 & 18.47 & 1.04 \\
\hline \multicolumn{6}{|c|}{2014 season } \\
\hline \multicolumn{6}{|c|}{ Intercropping patterns: } \\
\hline Rep 4:2 & 5.22 & 7.80 & 3.04 & 16.06 & 0.89 \\
\hline Rep 2:1 & 5.46 & 8.05 & 2.64 & 16.15 & 0.9 \\
\hline Add 1 & 5.80 & 11.59 & 1.17 & 18.56 & 1.03 \\
\hline Add 2 & 5.60 & 11.83 & 1.21 & 18.64 & 1.04 \\
\hline \multicolumn{6}{|c|}{ Periodical cutting systems: } \\
\hline C1: $40-40-40$ & 5.81 & 12.18 & 1.92 & 19.91 & 1.11 \\
\hline C2: $45-30-45$ & 5.46 & 11.89 & 1.87 & 19.22 & 1.07 \\
\hline C3: $45-45-30$ & 5.29 & 11.32 & 2.27 & 18.88 & 1.05 \\
\hline
\end{tabular}

* compared to pure maize total dry matter (grain + straw $=17.72$ and 17.96 t/ha in 2013 and 2014 seasons, respectively.

\section{Discussion}

Modification in the environment of plant growth to be suitable habitation for plants has been important to improve plant growth performance. Data indicated that the tallest maize plants were obtained from the additive intercropping, however, the minimum values of that trait were produced by replacement 
patterns. Competition between plants for light was greatly affected by millet first duration of association. Increasing that period increased competition for light causing maize plants to be tallest (Khalil \& Nawar, 2004 and Hauggaard-Nielsen et al., 2009). Maize grown with equi-intervals of 40 days for cutting millet (C1) enabled maize to grow throughout its growing season with low competition from millet. That will lead to more uptake of growth factors, higher photoassimilates production and translocation into ears more than the other (C2 and $\mathrm{C} 3$ ) periodical cutting systems (Gardner et al., 1985). That may be due to the occurrence of competition at different stages of growth of maize. As mentioned before, competition in $\mathrm{C} 1$ system was low at critical stages of maize growth [(emergence and establishment (stage 1), rapid vegetative growth (stage 2) and grain development (stage 3)]. However, in C2 system, maize suffered from higher degree of competition in stages 1 and 3, whereas in $\mathrm{C} 3$ system, maize was subjected to a high degree of competition in stages 1 and 2 . The variation in degree of competition will affect maize plants ability to use available resources for growth and grain formation, leading to a decrease in available photoassimilate translocated to the grains (Ranson, 2013), especially at critical periods which determine kernel number in the ear (around seven weeks after emergence) (Andrade et al., 1999 and Kasem et al., 2003) and influence grain filling (around 11 to 12 weeks after emergence) (Ranson, 2013). The lower competition in $\mathrm{C} 1$ system resulted in higher values for both 100-grain weight and ear weight compared to $\mathrm{C} 2$ and $\mathrm{C} 3$ systems, which finally led to higher grain yield and harvest index. Increases in DMER showed the more efficient use of land in additive intercropping, compared with replacement intercropping or maize grown alone. These results reflected the ability of maize/millet intercropping in additive patterns to better utilize growth resources than growing the two intercrops in replacement patterns (Blair et al., 2006; Egli, 2008 and Brintha \& Seran, 2009). However, DMER values of more than one might be due to increases in plant population densities with better use in growth resources in additive than in replacement intercropping (Midya et al., 2005). Data showed that millet fresh fodder and dry matter yields were closely related to its sown area and orientation with maize plants. Reduction in fodder yield in additive intercropping (compared to intercropping in replacement model) might be due to the shading effect of maize plants on millet. However, it could be concluded that yields of fodder millet, within the intercropping combination, were proportionally parallel with millet population density within these intercropping patterns (Willy 1979 "a and "b").

Intercropping of maize and fodder millet in replacement combination produced lower dry matter, compared to that obtained from maize-millet additive intercropping. That could be explained due to the increase in the total population density per intercropping unit and better use of environmental resources in additive than when the two crops were grown in replacement series (Fukai \& Trenbath, 1993). DMER varied with periodical cutting systems and had values greater than one, indicating that this procedure exhibits intercropping advantages than when maize plants were grown in pure stands (Willy 1979 "a and "b"). Since DMER values were higher for Add 1 and Add 2 compared to Egypt. J. Agron. 38, No. 3 (2016) 
Rep 1 and Rep 2, it could be concluded the suitability of growing maize with fodder millet in additive series without reduction in maize grain yield. That method will provide an additional forage yield during summer season, where green fodder is scarce, in Egypt. The amount of that forage crop will depend on the percentage of millet added to grain maize.

Acknowledgment: The authors wishes to express their deepest gratitude and sincere appreciation to Dr. Ali Issa Nawar, Professor of Crop Science Department, Faculty of Agriculture, Alexandria University, for his supervision, valuable comments, advice, valuable suggestions in the nature of the research problem and plan of work and helpful assistance in writing and reviewing the manuscript. Sincere appreciation, also, is given to Dr. Hassan Khalil, Professor of Crop Intensification Dept., Field Crop Research Institute, Agriculture Research Center, for his supervision and encouragement during the progress of this study and for reviewing the manuscript. Deepest appreciation is due to all staff members of Intertek Testing Services Caleb Brett Egypt LTD, for their help and providing any facility for this work.

\section{References}

Andrade, F.H., Vega, C., Uhart, S., Cirilo, A., Cantarero, M. and Valentinuz, O. (1999) Kernel number determination on maize. Crop Sci. 39, 543-549.

Anil, L.J., Phipps, R.H. and Miller, F. A. (1998) Temperate intercropping of cereals for forage, a review of potential for growth and utilization with practical reference to the UK. Grass Forage Sci. 51, 301-312.

Blair, N., Faulkner, R.D. and Poulton, P.R. (2006) Long term management impacts on soil. C,N and Physical Fertility. Soil and Tillage Res. 91, 30-39

Brintha, I. and Seran, T.H. (2009) Effect of paired row planting of Radish (Raphanus sativus L.) intercropped with vegetable amaranths (Amaranths tricolor L.) on yield components of radish in sandy regosol. J. Agric. Sci. 4, 19-28.

Egli, D.B. (2008) Comparison of corn and soybean yields in the United States .Historical trends and future prospects. Agron. J. 100, (Suppl), 79-88.

Francis, R. and Decoteau, D.R. (1993) Developing and effective southern pea and sweet corn intercrop system. Horttechnology, 3, 178-184.

Fukai, S. and Trenbath, S. (1993) Intercropping basses of productivity. Field Crop Res. 34, 239245.

Gao, Y., Duan, A.W., Sun, J.S., Li, F.S., Liu, H. and Liu, Z.D. (2009) Crop coefficient and water use efficiency of winter wheat, spring maize strip intercropping. Field Crop Res. 111, 65-73.

Gardner, F.B., Peacre, R.B. and Nit chell, R.L. (1985) "Physiology of Crop Plants". Iowa State Univ. Press, Ames, Iowa, U.S.A. 
Gomez, K.A. and Gomez, A.A. (1984) "Statistical Procedures for Agriculture Research". $2^{\text {nd }}$ ed. John Wiley and Sons, New York, U.S.A.

Gou, F., Martin Van Ittersum, G. Wang, Van der Putten, P.E. and Van der Werfa, W. (2016) Yield and yield components of wheat and maize in wheat-maize intercropping in Netherlands. Eur. J. Agron, 76, 17-27.

Hauggaard-Nielsen, H., Gooding, M., Ambus, P., Corre-Hellou, G., Crozat, Y., Dahlmann, C., Dibet, A., von Fragstein, P., Pristeri, A., Monti, M. and Jensen, E. S. (2009) Pea-barley intercropping and short-term subsequent crop effects across European organic cropping conditions. Nutrient Cycling in Agroecosystems, 85 (2), 141-155.

Kasem, A.A., Omar, A.O. and Nawar, A.I. (2003) Maize "Production of Field Crops". Alex Univ., Egypt (in Arabic): pp. 131-166.

Khalil, H.E. and Nawar, A.I. (2004) Productivity of maize and soybean association patterns after different winter crops. Minufiya J. Agric. Res. 29 (3), 679-693.

Midmore, D.J. (1993) Agronomic modification of resource use and intercrop productivity. Field Crop Research, 34, 357-381.

Midya, A., Battacharjee, K., Ghose, S.S. and Banik, P. (2005) Deferred seeding of black gram (Phaseolus mungo L.) in rice (Oryza sativa L.) field on yield advantages and smothering of weeds. J. Agron \& Crop Sci. (191), 195-201.

Ranson, J. (2013) "Corn Growth and Management". North Dakota State University, Extension Service, Fargo, North Dakota.

SAS Institute, Inc., (2007) SAS Technical Report SAS/STAT Software: Changes and Enhancements User's Guide, Volume 2, Version 9.1.3, Fourth Edition, Cary, NC: SAS Institute, Inc.

Shaalan, A.M., Khalil, H.E., Nawar, A.I. and El-salamouni, M.M. (2015) Intercropping of grain and fodder maize crops under different nitrogen levels and cutting dates. Alex. Sci. Exch. J. 36, (4), 373-380.

Vandermeer, J. (1989) "The Ecology of Intercropping". Cambridge University Press, Cambridge

Willy, R.W. (1979 a) Intercropping-its importance and research needs. Part 1: competition and yield advantage. Field Crop Abstracts, 32,1-10.

Willy, R.W. (1979 b) Intercropping-its importance and research needs. Part 2: agronomy and research approaches. Field Crop Abstracts, 32, 73-85.

Wolfe, M.S. (2000) Crop strength through diversity. Nature, 406, 681-682.

Zhu, J., Van der Werf, W., Anten, N.P.R., Vos, J. and Evers, J.B. (2015) The contribution of phenotypic plasticity to complementary light capture in plant mixtures. New Phytol. 207, 12131222.

(Received 28/10/2016; accepted 8/12/2016)

Egypt. J. Agron. 38, No. 3 (2016) 


\title{
انتاجية محصول الأرة و علف الاخن تحميل تحت نظم مختلفة

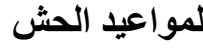

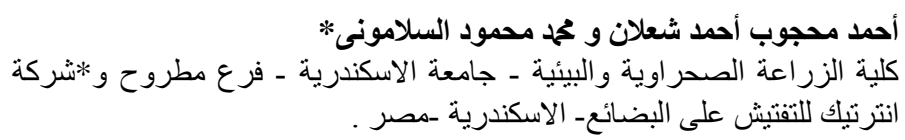

\begin{abstract}
أجريت تجربتان حقليتان بمحطة البحوث الزر اعية - جامعة الأسكندرية - مصر

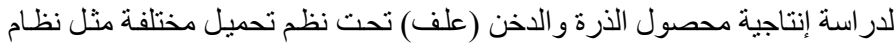

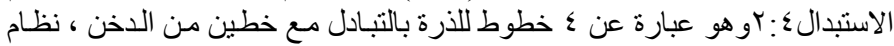

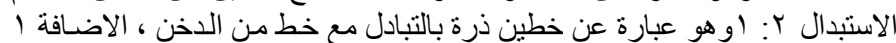

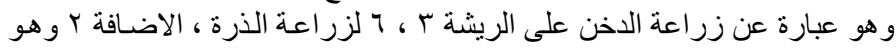

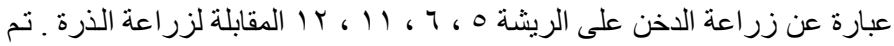

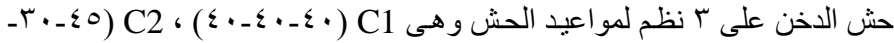

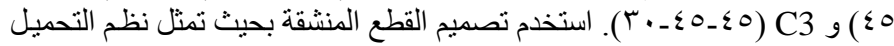

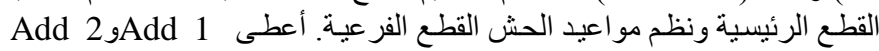

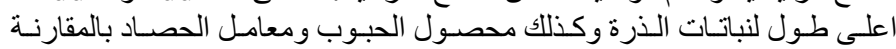

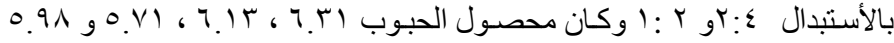

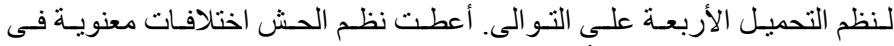

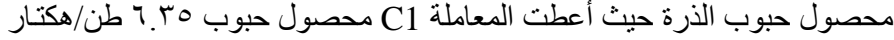

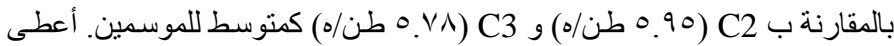

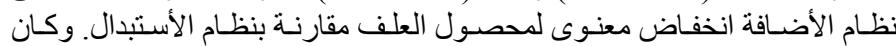

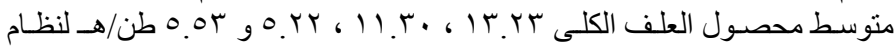

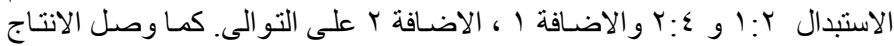

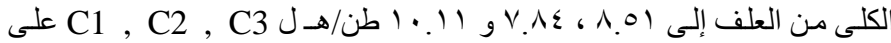

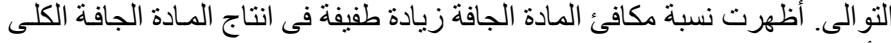
لملأضافة مقارنة بالاستبدال لنظم التحميل.
\end{abstract}

